\title{
Lung Large Cell Carcinoma
}

National Cancer Institute

\section{Source}

National Cancer Institute. Lung Large Cell Carcinoma. NCI Thesaurus. Code C4450.

An undifferentiated non-small cell lung carcinoma composed of large polygonal cells without evidence of glandular, squamous, or neuroendocrine differentiation. 